\title{
Enzim Laccase dari Edible Mushroom untuk Pemutihan Pati Sagu Ramah Lingkungan
}

\section{Laccase Enzyme from Edible Mushroom for Bioleaching Sago Starch with Environmental Friendly}

\author{
BUDHI SANTOSO REKSOHADIWINOTO', SYOFI ROSMALAWATI', \\ PURWA TRI CAHYANA ${ }^{1}$ DAN BAMBANG HARIYANTO' \\ ${ }^{1}$ Pusat Teknologi Agroindustri, Badan Pengkajian dan Penerapan Teknologi \\ ${ }^{2}$ Balai Bioteknologi, Badan Pengkajian dan Penerapan Teknologi \\ Gedung 610 (Laptiab) dan 630 (Biotek) Puspiptek Serpong Tangerang Selatan \\ budhi.santoso@bppt.go.id
}

\begin{abstract}
Sago generally has brown color and unpleasant smells. This drawback can be improved with the addition of laccase enzyme in the production of sago starch. The purpose of this study is to produce enzm laccase of edible mushroom. Materials used are Plurotus ostreatus mushroom, Agaricus bisporus and Rhyzopus oligosporus obtained from the market and chemicals medium. The method is through the use of liquid fermentation flask scale. The results showed that Pleurotus ostreatus in order to test the petri dish to form zones thick brownish red ring shows the ability of compounds guaicol and syringaldazine oxidase. Test liquid fermentation scale flaks $500 \mathrm{~mL}$ culture of Pleurotus ostreatus mushroom, Agaricus bisporus, Rhyzopus oligosporus for 21 days. Results laccase produced by Pleurotus ostreatus have the highest activity reached $774 \mathrm{U} / \mathrm{L}$ in the analysis spectrophotometer using ABTS substrate. Meanwhile, Agaricus bisporus and Rhyzopus oligosporus reach peak production of laccase each $484 \mathrm{U} / \mathrm{L}$ and $480 \mathrm{U} / \mathrm{L}$
\end{abstract}

Keywords: Pleurotus ostreatus, Agaricus bisporus, Rhyzopus oligosporus, laccase, bioleaching, sago quality

\section{ABSTRAK}

Sagu pada umumnya berwarna kecoklatan dan bau kurang sedap. Kelemahan ini dapat diperbaiki dengan penambahan enzim Laccase dalam produksi pati sagu. Tujuan penelitian ini adalah menghasilkan enzm Laccase dari edible mushroom. Bahan yang digunakan adalah jamur Plurotus ostreatus, Agaricus bisporus dan Rhyzopus oligosporus yang diperoleh dari pasar dan bahan kimia media. Metoda yang digunakan adalah melalui fermentasi cair menggunakan skala flask. Hasil yang diperoleh bahwa Pleurotus ostreatus pada uji agar cawan petri membentuk zona ring merah kecoklatan yang tebal menunjukan kemampuan oxidase senyawa guaicol dan syringaldazine. Uji fermentasi cair skala flaks $500 \mathrm{~mL}$ kultur jamur Pleurotus ostreatus, Agaricus bisporus, Rhyzopus oligosporus selama 21 hari. Hasil Laccase yang diproduksi oleh Pleurotus ostreatus mempunyai aktivitas tertinggi yaitu mencapai $774 \mathrm{U} / \mathrm{L}$ pada analisa spektrofotometer menggunakan substrat ABTS. Sementara itu, Agaricus bisporus dan Rhyzopus oligosporus mencapai puncak produksi laccase masing-masing $484 \mathrm{U} / \mathrm{L}$ dan 480 $\mathrm{U} / \mathrm{L}$.

Kata kunci : Pleurotus ostreatus, Agaricus bisporus, Rhyzopus oligosporus, Laccase, bioleaching, dan kualitas pati sagu

\section{PENDAHULUAN}

\subsection{Latar Belakang}

Luas hutan sagu di Indonesia diperkirakan mencapai 4,18 juta hektar ${ }^{(1,2)}$ namun demikian baru dimanfaatkan sebagian kecil untuk produksi pati sagu. Pada tahun 2014, produksi pati sagu Indonesia mencapai 585 ribu ton per tahun dan merupakan yang terbesar di dunia ${ }^{(3)}$ dalam Naim $\mathrm{dkk}^{(4)}$, bersama Papua New Guinea menguasai 94,6 persen produksi pati sagu dunia. Meskipun produksi pati sagu Indonesia terbesar, namun kualitas pati sagu kurang bagus karena warna yang cenderung putih kecoklatan (brownish). Sedangkan kualitas pati sagu ditentukan oleh warna, viskositas, dan ukuran partikel ${ }^{(5)}$. Warna coklat di pati sagu dikarenakan adanya kandungan senyawa polyphenol ${ }^{(6)}$. Warna Sagu yang baik dan mempunyai nilai ekonomi yang tinggi adalah warna putih cerah dan tidak terdapat butiran warna hitam.

Selama ini pengrajin pati sagu menggunakan pemutih kimiawi seperti: tawas, benzoil, peroksida, kalium bromate, kalsium iodat, dan 
asam ascorbat. Beberapa senyawa phenol tidak diperkenankan dalam bahan pangan dan pemutih kimiawi karena berbahaya bagi kesehatan. Untuk itu perlu pengolahan sagu yang memenuhi standar keamanan pangan. Pengolahan pati sagu menggunakan bahan pemutih alami yang ramah lingkungan seperti enzim laccase diharapkan lebih aman dan ramah lingkungan.

\subsection{Tinjauan Pustaka}

Laccase adalah enzim yang dapat mengoksidasi senyawa aromatik dan non aromatik pada spectrum yang luas yang terbentuk oleh aktivitas mikroba maupun tanaman. Laccase tumbuh secara luas dalam tanaman tingkat tinggi, jamur Ascomycetes, Deuteromycetes, dan Basidio-mycetes, serta bakteri ${ }^{(7)}$. Studi beberapa jenis jamur dan bakteri yang menghasilkan laccase mempunyai kemampuan dalam pengurangan warna pada mikropolutan senyawa phenol telah dilakukan Forootanfar dkk ${ }^{(8)}$ dan Margot dkk ${ }^{(9)}$.

Beberapa jenis jamur atau bakteri yang memproduksi laccase diantaranya Pleurotus ostreatus, Penicillium chrysogenum, Agaricus bisporus, Fusarium solani ${ }^{(10)}$, Aspergillus sp., Rhizopus $s p$., Fusarium sp., Penicillium $s p$., Alternaria sp. ${ }^{(11)}$, Lentinula edodes ${ }^{(12,26)}$, Trametes versicolor $^{(13)}$, Trichoderma, Leptosphaerulina, Bacillus substilis ${ }^{(14)}$, Pseudomonas aeruginosa, dan Pseudomonas fluorescens ${ }^{(15)}$, dan Lactobacillus, yang menghasilkan senyawa oxidoreductase yang bersifat bioleaching $(9,10,11,12,13)$. Laccase adalah enzim lignolitik yang mampu mengoksidasi $\mathrm{Cu}$, terlibat dalam crosslinking monomer, degradasi senyawa polymer dan pembukaan cincin senyawa komplek aromatik ${ }^{(16)}$. Edible mushroom dapat memproduksi laccase dan dapat diisolasi dari alam dan dikultivasi untuk menghasilkan protein laccase bioleaching. Isolasi dan seleksi jamur Pleurotus ostreatus, Agaricus bisporus, Volvariela volvacea dan jamur Rhyzopus oligosporus digunakan sebagai model dalam fermentasi cair jamur untuk produksi laccase bioleaching.

Jamur kancing (Agaricus bisporus) atau dikenal juga dengan nama champignon adalah jamur pangan berbentuk bulat berwarna putih. Jamur kancing dipanen sewaktu masih berdiameter 2-4 cm. Jamur kancing dijual dalam bentuk segar atau kalengan, digunakan dalam berbagai masakan Barat seperti omelet, pizza, kaserol, gratin, dan selada. Jamur kancing dapat tumbuh pada kayu lapuk atau sekam karena memanfaatkan sisa karbon sebagai sumber energinya. Kemampuan biokonversi lignosellulosa jamur kancing ini dikarenakan jamur kancing mampu memproduksi kelompok enzim lignolitik, salah satu diantaranya adalah Laccase yang merupakan enzim ekstra selluler multi copper yang mampu mengoksidasi komponen struktur aromatik dan non aromatik pada struktur lignin ${ }^{(10)}$.

Jamur tiram (Pleurotus ostreatus) merupakan jamur pangan kelompok Basidiomycota, termasuk Homobasidiomycetes dengan ciri umum tubuh buah berwarna putih hingga krem dan tudungnya berbentuk setengah lingkaran mirip cangkang tiram dengan bagian tengah agak cekung. Tubuh buah jamur tiram memiliki tangkai yang tumbuh menyamping (bahasa Latin: pleurotus) dan bentuknya seperti tiram (ostreatus) sehingga jamur tiram mempunyai nama binomial Pleurotus ostreatus. Selain itu, menurut ${ }^{(11)}$ jamur tiram juga memiliki spora berbentuk batang berukuran 8-11 $\times$ 3-4 $\mu \mathrm{m}$ serta miselia berwarna putih yang bisa tumbuh dengan cepat. Di alam bebas, jamur tiram bisa dijumpai hampir sepanjang tahun di hutan pegunungan daerah yang sejuk.

\subsection{Tujuan}

Tujuan penelitian ini adalah mendapatkan enzim laccase dari edible mushroom untuk bioleaching pati sagu yang ramah lingkungan.

\section{BAHAN DAN METODE}

\subsection{Bahan Kimia Dan Sample Edible Mushroom}

Sampel edible mushroom diperoleh dari pasar, sedangkan bahan kimia untuk analisa menggunakan bahan analytical grade: ABTS (Merck), Syringaldazine (Sigma), Guaiacol (Sigma), KH2PO4 (Merck), K2HPO4 (Merck), Ammonium sulfate (Merck), Sodium phosphate (Merck). Sementatra itu bahan fermentasi digunakan kombinasi bahan kimia pro analysis (PA) dan bahan teknis.

\subsection{Isolasi Edible Jamur pada Media PDA (Potato Detrose Agar)}

Isolasi edible jamur dari jamur tiram (Pleurotus ostreatus), Jamur kancing (Agaricus bisporus), dan (Rhyzopus oligosporus) yang ada di pasar, mengacu pada metode isolasi ${ }^{(17,18)}$ yang dimodifikasi, menggunakan media potato dextrose agar (PDA) yang mengandung ekstrak potato 20 $\%$, dextrose $2 \%$ dan agar $2 \%$ dilarutkan pada destilled water dengan $\mathrm{pH}$ 7,0 dan inkubasi statis pada ruang gelap dengan temperatur $25 \pm 2{ }^{\circ} \mathrm{C}$ selama 7 hari. Miselia yang tumbuh selanjutnya di subkultur untuk mendapatkan isolate murni jamur yang dimaksud. Sub-kultur isolate jamur $A$. bisporus, $P$. ostratus, dan $R$. oligosporus dilakukan pada media Potato Dextrose Agar (PDA) mengacu pada metode ${ }^{(17)}$ yang dimodifikasi. Pada PDA $24 \mathrm{gL}^{-1}$ yang diperkaya 
yeast ekstrak 0,5 \% dan mikromineral ditanam potongan $A$. bisporus, $P$. ostratus, dan $R$. oligosporus, diinkubasi pada suhu $30{ }^{\circ} \mathrm{C}$ selama 7 hari. Selanjutnya hasil sub-kultur jamur tersebut digunakan sebagai inokulum pada fermentasi cair.

\subsection{Uji Laccase pada Cawan Agar Plate}

Uji laccase pada cawan agar menggunakan guaiacol dan syringaldazine. Seleksi jamur edible mushroom dilakukan mengacu pada metode ${ }^{(10)}$. Potongan edible jamur tiram (Pleurotus ostreatus), jamur kancing (Agaricus bisporus), dan jamur tempe (Rhyzopus oligosporus) di tanam pada media

Potato Dextrose Agar yang ditambahkan 0.02 $\%$ guaiacol dan 0,1 \% syringaldazine. Warna merah kecoklatan atau orange disekitar koloni menjadi indikator positif adanya laccase pada guaiacol dan warna ungu pada syringaldazine.

\subsection{Kultur Fermentasi Cair Jamur Edible pada Media PDB (Potato Detrose Broth)}

Kultur fermentasi cair jamur edible $A$. bisporus dan $P$. ostratus menggunakan media Potato Dextrose Broth (PDB) mengacu pada metode ${ }^{(10,21)}$ yang dimodifikasi. Media PDB yang diperkaya dengan mikromineral dilarutkan dalam $100 \mathrm{~mL}$ air destilasi pada $250 \mathrm{~mL}$ flask Erlenmeyer. Media mengandung dextrose $1 \%$, peptone $0,3 \%$, $\mathrm{KH}_{2} \mathrm{PO}_{4}$ 0,06 \%, ZnSO ${ }_{4}$ 0,0001\%, $\mathrm{K}_{2} \mathrm{HPO}_{4} \quad 0,04$ $\%, \mathrm{FeSO}_{4} 0.0005 \%, \mathrm{MnSO}_{4} 0.05 \%$ dan $\mathrm{MgSO}_{4}$ $0.05 \%$, dengan pH 6.0 sterilisasi pada $121^{\circ} \mathrm{C}$ selama 15 menit. Selanjutnya Erlenmeyer flask diinokulasi dengan potongan agar cawan petri miselium jamur $A$. bisporus dan $P$. ostratus dari PDA sebesar $1 \mathrm{~cm}^{2}$ masing-masing sebanyak 3 buah dan diinkubasi pada suhu $30{ }^{\circ} \mathrm{C}$ dalam waterbath shaker incubator 100 rpm kondisi gelap selama 7 hari. Sampling dilakukan mulai hari ke-4 sampai dengan hari ke-7 setelah fermentasi untuk dilakukan analisa Laccase. Pengujian fermentasi laccase juga dilakukan pada kultur jamur P.ostretus, A.bisporus, dan R.oligosporus menggunakan bahan media fermentasi cair mengacu pada metode ${ }^{(10,21)}$ yang dimodifikasi dengan substitusi sumber karbon dan sumber protein. Sampling dilakukan pada hari ke-0, 3, 6 , $9,12,15,18$, dan 21.

\subsection{Ekstraksi Laccase}

Ekstraksi Laccase dilakukan secara bertahap pada kultur fermentasi cair pada hari ke-4, 5, 6, dan 7 setelah fermentasi mengacu pada metode $(19,20,21)$ yang dimodifikasi.

Ekstraksi Laccase pada broth fermentasi dilakukan dengan cara presipitasi protein menggunakan larutan ammonium sulfat jenuh (80\%), pendinginan pada suhu $4{ }^{\circ} \mathrm{C}$ selama dua jam dan sentrifuge pada $10.000 \times$ g selama 15 menit.

\subsection{Analisa Laccase}

Analisis pada filtrate dengan menggunakan

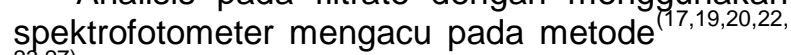
23,27) yang dimodifikasi. Analisis pada Thermo Scientific spektrofotometer dilakukan pada larutan yang dicampurkan dengan dua cara yaitu pertama, mencampurkan $1 \mathrm{~mL}$ filtrate enzim Laccase, $2 \mathrm{~mL}$ buffer phosphate $50 \mathrm{mM} \mathrm{pH} \mathrm{6,0,}$ dan $1 \mathrm{~mL}$ Guaicol $2 \mathrm{mM}$ dengan waktu inkubasi 20 menit pada suhu ruang dan panjang gelombang $470 \mathrm{~nm}$. Kedua, mencampurkan $1 \mathrm{~mL}$ filtrate enzim Laccase, $2 \mathrm{~mL}$ buffer phosphate 50 $\mathrm{mM} \mathrm{pH}$ 6,0, dan $1 \mathrm{~mL}$ ABTS $0.45 \mathrm{mM}$ dengan waktu inkubasi 20 menit pada suhu ruang dan panjang gelombang $420 \mathrm{~nm}$.

Perhitungan aktivitas enzim dilakukan sesuai dengan metode Desai dkk (17) yaitu Aktivitas Enzim $(\mathrm{U} / \mathrm{mL})=$ Absorbansi spektrofotometer $\mathrm{x}$ Volume total larutan / (volume enzim x waktu inkubasi $x$ koefisien enzim guaiacol (12.100 $\mathrm{M}^{-1}$ $\mathrm{cm}^{-1}$ ) atau ABTS (36.000 $\left.\mathrm{M}^{-1} \mathrm{~cm}^{-1}\right)$.

\section{HASIL DAN PEMBAHASAN}

Pati sagu dihasilkan dengan cara pemarutan batang sagu yang dilanjutkan dengan ekstraksi menggunakan air mengalir. Kejernihan dan $\mathrm{pH}$ air sangat berpengaruh pada hasil pati sagu yang diekstraksi. Sagu yang baik dan dikehendaki oleh masyarakat adalah warna putih cerah dan tidak ada bintik-bintik noda hitam. Dalam proses ektraksi pati sagu, terjadi perubahan warna empulur dari putih menjadi pink dan akhirnya merah kecoklatan yang disebabkan oleh reaksi oksidasi senyawa polyphenol di empulur sagu. Perubahan warna tersebut sangat dipengauhi oleh kondisi tanah dan keasaman yang terjadi akibat adanya unsur logam $\mathrm{Mn}, \mathrm{Fe}, \mathrm{Mg}$ dan air yang mengandung sulfur membentuk reaksi oksidasi. Fenomena ini telah diteliti oleh $^{(24)}$ yang menyebutkan warna pada pati sagu hasil ekstraksi dipengaruhi oleh kondisi keasaman tanah dan kandungan sulfur tempat tumbuhnya tanaman sagu. Kadar asam dan kandungan sulfur yang tinggi menyebabkan kandungan abu dan senyawa phenolic yang tinggi sehingga warna pati sagu menjadi pink sampai merah kecoklatan dan akhirnya menjadi kelam/kelabu.

Empulur sagu secara alami mengandung mikroba indigeneous mempunyai fungsi dalam perubahan biosintesa bahan alam sagu melalui proses degradasi natural. Mikroba indigeneous sagu bisa diisolasi dan dikultur untuk dimanfaatkan sesuai dengan potensinya, diantaranya potensi produksi laccase enzim. Seleksi dan analisis diversitas mikroba sagu untuk bioleaching dilakukan dengan pendekatan isolasi metagenomik DNA mikroba sagu dan isolasi 
jamur edible mushroom yang menghasilkan laccase sebagai bioleaching. Selanjutnya dilakukan uji produksi laccase pada cawan agar dan fermentasi serta analisis aktivitas laccase. Strain terbaik dari hasil isolasi kedua pendekatan tersebut digunakan sebagai starter inokulum dalam produksi laccase skala fermentor dan purifikasi laccase.

\subsection{Isolasi Jamur Edible Mushroom}

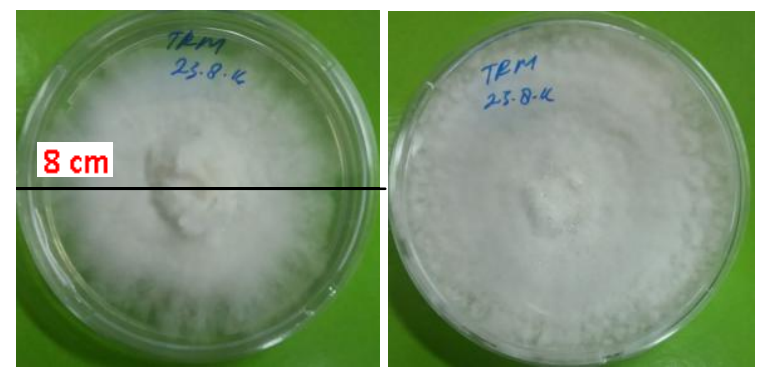

Gambar 1. Jamur tiram umur miselia 4 hari (kiri) dan 6 hari (kanan)

Jamur edible mushroom diisolasi dari jamur yang terdapat di pasar dengan menumbuhkan fruiting bodies jamur tiram (P.ostreatus) dan jamur kancing (A.bisporus) pada media agar cawan petri Potato Dextrose Agar. Setelah miselia tumbuh, dilakukan sub kultur sampai diperoleh kultur murni.

Hasil Pengukuran pertumbuhan miselia jamur tiram Pleurotus ostreatus (jamur tiram) dilakukan pada cawan petri diameter $8 \mathrm{~cm}$ menggunakan potongan agar slant $1 \mathrm{~cm}^{2}$. Miselia dapat tumbuh dengan cepat, menutup penuh permukaan agar dalam 6 hari masa inkubasi.

Jamur tiram ini juga mempunyai kemampuan produksi Laccase secara ekstraselluler yang telah dipurifikasi dan dikarakterisasi secara molekuler Okamoto $\mathrm{dkk}^{(19)}$.

Selanjutnya, pertumbuhan miselia jamur $P$. ostreatus tetap berwarna putih sedangkan miselia A. bisporus berubah menjadi hitam. Kecepatan pertumbuhan miselia jamur $A$. bisporus lebih cepat daripada jamur $P$. ostreatus. Karena itu jamur $A$. bisporus lebih cepat membentuk spora ketika nutrisi yang tersedia tidak mencukupi kebutuhan untuk pertumbuhan miselia selanjutnya. Studi tentang pertumbuhan kinetic miselia $A$. bisporus pernah dilakukan oleh Straatsma dk ${ }^{(25)}$, dimana kecepatan pertumbuhan miselia bisa mencapai $30 \mathrm{mmd}^{-1}$ pada pertumbuhan eksponensialnya sedangkan pada fase stasionernya hanya mencapai 7,2 $\mathrm{mmd}^{-1}$.

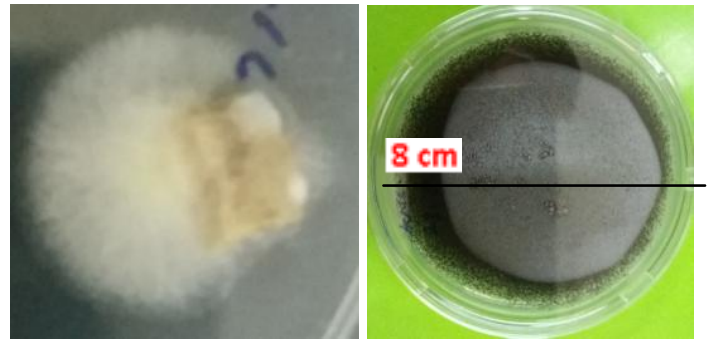

Gambar 2. Jamur kancing umur miselia 2 hari (kiri) dan 9 hari (kanan)

Pengujian aktivitas Laccase dilakukan pada media cawan PDA agar dengan menambahkan larutan guaicol dan syringaldehide. Pada kultur induk masing-masing dilakukan sub-kultur miselia jamur $A$. bisporus dan $P$. ostreatus dan diinkubasi pada suhu $30{ }^{\circ} \mathrm{C}$ selama 7 hari. Adanya aktivitas Laccase ditunjukkan oleh terbentuknya zona warna coklat orange yang merupakan hasil oksidasi substrat guaicol dan syringaldehida oleh Laccase. Semakin besar konsentrasi Laccasenya akan membentuk zona coklat kemerahan yang semakin luas. Hasil uji laccase test menunjukkan bahwa jamur Pleurotus mempunyai kemampuan menghasilkan laccase dan melakukan oksidasi guaiacol dan syringaldazine.

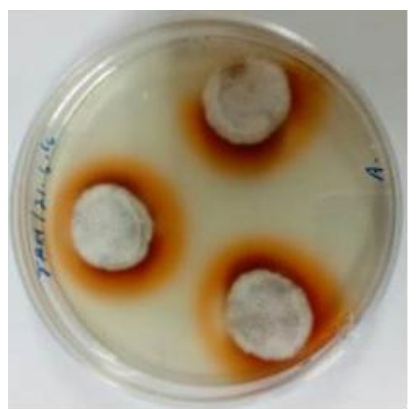

Gambar 3. Zona coklat orange indikasi aktivitas laccase pada media cawan petri PDA

\subsection{Uji Fermentasi Jamur Edible Mushroom}

Pada uji coba fermentasi cair menggunakan potongan jamur edible $A$. bisporus dan $P$. ostreatus secara langsung pada media fermentasi cair tidak berhasil. Hal ini dikarenakan miselia tidak mampu tumbuh atau menggunakan sumber karbon yang berasal dari gula sederhana seperti sukrosa dan dekstrosa. Media fermentasi tetap bening setelah fermentasi berlangsung selama 4 hari, sedangkan fermentasi menggunakan inokulum yang berasal dari sub-kultur miselia kedua jamur pada media agar PDA menunjukan pertumbuhan miselia yang ditandai dengan kekeruhan pada media kultur fermentasi cair seperti dapat dilihat pada gambar di bawah. 
Namun demikian, tingkat kekeruhan media kultur fermentasi cair tidak selalu mencerminkan pertumbuhan miselia jamur saja tetapi juga dipengaruhi oleh pertumbuhan kontaminan bakteri yang bersimbiosis pada miselia jamur. Pada kultur fermentasi jamur yang steril, tidak menunjukkan kekeruhan meskipun pertumbuhan miselia jamur tampak subur dan media kultur fermentasi cair tetap bening. Fenomena ini memberikan gambaran bahwa pada kultur fermentasi cair jamur tidak selalu memberikan hasil kekeruhan pada media cair fermentasi yang menunjukkan adanya pertumbuhan miselia jamur tetapi juga dapat media kultur fermentasi cair tetap bening. Sementara itu, pada pemeriksaan mikroskopis media kultur fermentasi cair yang keruh, tidak menunjukkan secara jelas adanya kontaminasi.

Temperatur suhu ruang pada saat analisa spektrofotometer mencapai $34^{\circ} \mathrm{C}$, sedangkan suhu ruang yang direkomendasikan untuk analisa dalam reaksi enzimatis adalah $25^{\circ} \mathrm{C}$. Kemungkinan lain adalah produksi Laccase oleh A. bisporus memang kecil, hal ini dikarenakan pertumbuhan jamur $A$. bisporus terkontaminasi bakteri apabila dilihat dari tingkat kekeruhan media kultur fermentasi cair. Pada flask Erlenmeyer dengan kode JB mengalami kekeruhan pada media, sedangkan pada flask Erlenmeyer $\mathrm{J}$ pertumbuhan miselia tidak mengalami kontaminasi bila dilihat dari kebeningan media kultur cairnya. Hal yang senada dilihat dari hasil absorbansi pada analisa spektrofotometer menunjukkan konsentrasi Laccase yang lebih tinggi bila dibandingkan dengan kultur dengan kode JB.

Hasil analisa konsentrasi Laccase pada absorbansi spektrofotometer kultur fermentasi $\mathrm{H}$ 5JB dan $\mathrm{H}$-6JB dengan perbedaan kecepatan sentifugasi memberikan pengaruh yang cukup signifikan. Hal ini dapat dilihat pada table $1 \mathrm{di}$ atas, dimana pada kecepatan sentrifugasi $4000 \mathrm{x}$ g H-5JB dan H-6JB konsentrasi Laccase masingmasing secara berurutan adalah 13,33 $\mu \mathrm{l}$ dan $16,00 \mu \mathrm{l}$ sedangkan pada kecepatan sentrifugasi $14.000 \times \mathrm{g}$ adalah $2,33 \mu \mathrm{l}$ dan $3,67 \mu \mathrm{l}$. Perbedaan nilai konsentrasi pada kecepatan sentrifugasi tersebut di atas disebabkan oleh perbedaan volume kultur yang disentrifugasi. Pada kecepatan $4.000 \times \mathrm{g}$ menggunakan tabung falcon $50 \mathrm{~mL}$ dengan volume kultur $25 \mathrm{~mL}$, sedangkan pada kecepatan $14.000 \times \mathrm{g}$ menggunakan ependof $2 \mathrm{~mL}$ dengan volume $1,5 \mathrm{~mL}$. Meskipun hasil analisa spektrofotometer menunjukkan angka yang berbeda namun demikian secara persentase pada sentrifuge menggunakan ependorf dapat memanen Laccase tiga kali lebih banyak bila dilihat dari perbandingan angka volume kultur yang disentrifugasi.
Tabel 1. Data analisis laccase pada

\begin{tabular}{|c|c|c|}
\hline \multicolumn{2}{|c|}{ Sampel } & \\
\hline \multicolumn{2}{|c|}{$4000 \times g$} & \\
\hline Blanko & air & 0.00 \\
\hline $\mathrm{H}-4 \mathrm{JB}$ & Lac4 & 2.67 \\
\hline $\mathrm{H}-5 \mathrm{JB}$ & Lac5 & 13.33 \\
\hline $\mathrm{H}-6 \mathrm{JB}$ & Lac6 & 16.00 \\
\hline $\mathrm{H}-7 \mathrm{JB}$ & Lac7 & 2.67 \\
\hline $\mathrm{H}-7 \mathrm{~J}$ & Lac7b & 23.33 \\
\hline \multicolumn{2}{|c|}{$14.000 \times g$} & \\
\hline $\mathrm{H}-5 \mathrm{JB}$ & Lac5 & 2.33 \\
\hline $\mathrm{H}-6 \mathrm{JB}$ & Lac6 & 3.67 \\
\hline
\end{tabular}

Sumber : hasil analisis spektrofotometer batch 1, 2016

Sementara itu, hasil pengujian konsentrasi Laccase pada ekstrak kultur fermentasi cair dapat dilihat pada table di atas dan grafik di bawah. Pada grafik menunjukkan adanya peningkatan konsentrasi Laccase sejak hari fermentasi ke-4 sampai dengan ke-6. Sedangkan pada hari fermentasi ke-7 mengalami penurunan konsentrasi Laccase yang cukup tajam kemungkinan dikarenakan Laccase telah habis atau terurai akibat panas suhu lingkungan. Temperatur suhu ruang pada saat analisa spektrofotometer mencapai $34^{\circ} \mathrm{C}$, sedangkan suhu ruang yang direkomendasikan untuk analisa dalam reaksi enzimatis adalah $25^{\circ} \mathrm{C}^{(20)}$. Kemungkinan lain adalah produksi Laccase oleh A. bisporus memang kecil, hal ini dikarenakan pertumbuhan jamur $A$. bisporus terkontaminasi bakteri $^{(28)}$ apabila dilihat dari tingkat kekeruhan media kultur fermentasi cair. Pada flask Erlenmeyer dengan kode JB mengalami kekeruhan pada media, sedangkan pada flask Erlenmeyer $\mathrm{J}$ pertumbuhan miselia tidak mengalami kontaminasi bila dilihat dari kebeningan media kultur cairnya. Hal yang senada dilihat dari hasil absorbansi pada analisa spektrofotometer menunjukkan konsentrasi Laccase yang lebih tinggi bila dibandingkan dengan kultur dengan kode JB. 


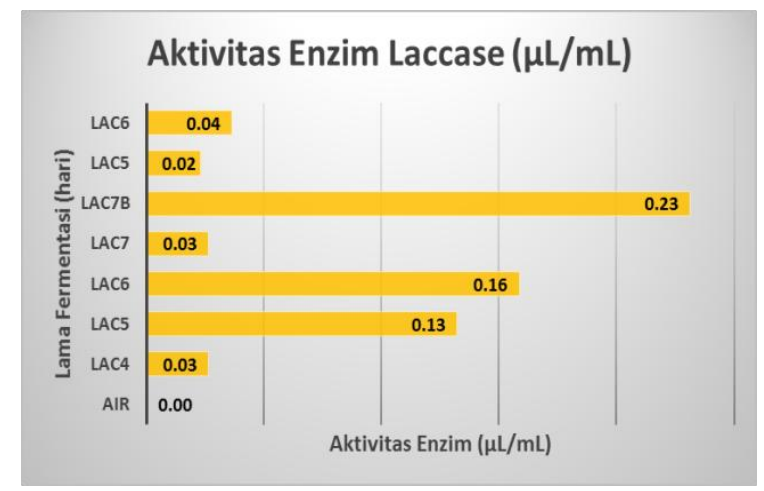

Gambar 4. Hasil uji aktivitas laccase A.bisporus menggunakan substrat Guaiacol

\subsection{Pengembangan Uji Fermentasi Jamur Edible Mushroom}

Isolasi edible mushroom dilakukan dengan mengambil sampel yaitu Pleurotus ostreatus, Agaricus bisporus, Volvariela volvacea dan Rhyzopus oligosporus diperoleh tiga strain yang terbaik yaitu Pleurotus ostreatus, Agaricus bisporus, dan Rhyzopus oligosporus. Hasil uji fermentasi dan aktivitas laccase pada substrat ABTS menunjukan aktivitas terbaiknya masingmasing adalah Pleurotus $774 \mathrm{U} / \mathrm{L}$ hari ke-21, Agaricus $484 \mathrm{U} / \mathrm{L}$ hari ke-9, dan Rhyzopus 480 $\mathrm{U} / \mathrm{L}$ hari ke-21. Data selengkapnya dapat dilihat pada Table 2. Secara umum hasil uji fermentasi tersebut belum menggunakan precursor untuk induksi laccase sudah cukup bagus bila dibandingkan hasil beberapa peneliti yang lain.

Tabel 2. Analisis Laccase hasil fermentasi jamur edible mushroom pada Spektrofotometer

\begin{tabular}{cccc}
\hline \multirow{2}{*}{$\begin{array}{c}\text { Hari } \\
\text { Fermen } \\
\text { tasi }\end{array}$} & \multicolumn{3}{c}{ Aktivitas Enzim $(\mathrm{U} / \mathrm{mL})$} \\
\cline { 2 - 4 } & $\begin{array}{c}\text { Agaricus } \\
\text { bisporus }\end{array}$ & $\begin{array}{c}\text { Rhyzopus } \\
\text { oligosporus }\end{array}$ & $\begin{array}{c}\text { Pleurotus } \\
\text { ostreatus }\end{array}$ \\
\hline 0 & 0.000 & 0.000 & 0.000 \\
3 & 0.368 & 0.297 & 0.288 \\
6 & 0.441 & 0.355 & 0.391 \\
9 & $\mathbf{0 . 4 8 4}$ & 0.398 & 0.319 \\
12 & 0.436 & 0.349 & 0.426 \\
15 & 0.423 & 0.327 & 0.376 \\
18 & 0.447 & 0.436 & 0.459 \\
21 & 0.378 & $\mathbf{0 . 4 8 0}$ & $\mathbf{0 . 7 7 4}$ \\
\hline
\end{tabular}

Sumber : hasil analisis spektrofotometer batch 3 , 2016

Guaiacol $0,04 \%$ digunakan oleh ${ }^{(23)}$ untuk skrening jamur laccase Trichoderma Spp pada uji fermentasi padat yang diperoleh aktivitas laccase sebesar $11,7 \mathrm{U} / \mathrm{mL}$ serta $8,67 \mathrm{U} / \mathrm{mL}$ pada fermentasi cair dengan waktu inkubasi selama 9 hari, pada temperatur optimum $45-50{ }^{\circ} \mathrm{C}$ dan $\mathrm{pH}$ 4,5 - 5,5 aktivitas enzim berkisar $80 \%$. Sedangkan peneliti lain ${ }^{(21)}$ menggunakan jamur Pleurotus ostreatus untuk produksi laccase dengan induksi CuSO4 $1 \mathrm{mM}$ diperoleh hasil terbaik $910 \mathrm{U} / \mathrm{L}$ selama 9 hari fermentasi meningkat dari $570 \mathrm{U} / \mathrm{L}$ tanpa induksi copper sulfat. Senyawa copper sulfat menjadi precursor yang lebih baik dibandingkan dengan veratrl alcohol $7 \mathrm{mM}$ dan benzyl alcohol $10 \mathrm{mM}$. Peneliti lainnya ${ }^{(11)}$, menggunakan Pleurotus $s p$ diperoleh hasil sebaliknya pada induksi tannic acid yaitu $83,83 \mathrm{U} / \mathrm{mL}$ dan $112,88 \mathrm{U} / \mathrm{mL}$ tanpa induksi. Hal ini menunjukkan tidak semua jenis precursor sesuai untuk produksi laccase. Peneliti ${ }^{(10)}$ bereksperimen pada pencarian sumber karbon dan sumber nitrogen menggunakan strain Aspergillus flavus diperoleh hasil produksi laccase terbaik pada sumber karbon selulose $8 \%$, nitrogen pepton $2 \%$, temp $35^{\circ} \mathrm{C}$ dan $\mathrm{pH} 7$ inokulum size $1,5 \mathrm{~cm}$.

Tabel 3. Data Analisis Kadar Gula Total hasil fermentasi jamur edible mushroom dengan refraktometer

\begin{tabular}{cccc}
\hline \multirow{2}{*}{$\begin{array}{c}\text { Hari } \\
\text { Fermentasi }\end{array}$} & \multicolumn{3}{c}{ Kadar gula total (\%) } \\
\cline { 2 - 4 } & $\begin{array}{c}\text { Agaricus } \\
\text { bisporus }\end{array}$ & $\begin{array}{c}\text { Rhyzopus } \\
\text { oligosporus }\end{array}$ & $\begin{array}{c}\text { Pleurotus } \\
\text { ostreatus }\end{array}$ \\
\hline 0 & 6.50 & 6.40 & 6.60 \\
3 & 6.12 & 6.01 & 6.05 \\
6 & 5.32 & 5.90 & 4.43 \\
9 & 4.63 & 5.98 & 4.80 \\
12 & 4.32 & 6.39 & 5.29 \\
15 & 4.38 & 6.24 & 6.14 \\
18 & 4.22 & 6.66 & 7.02 \\
21 & 4.70 & 7.52 & 7.63 \\
\hline
\end{tabular}

Sumber : hasil analisis refraktometer batch 3 , 2016 
Tabel 4. $\mathrm{pH}$ hasil fermentasi jamur edible mushroom dengan $\mathrm{pH}$ meter

\begin{tabular}{cccc}
\hline \multirow{2}{*}{$\begin{array}{c}\text { Hari } \\
\text { Fermentasi }\end{array}$} & \multicolumn{3}{c}{$\mathrm{pH}$} \\
\cline { 2 - 4 } & $\begin{array}{c}\text { Agaricus } \\
\text { bisporus }\end{array}$ & $\begin{array}{c}\text { Rhyzopus } \\
\text { oligosporus }\end{array}$ & $\begin{array}{c}\text { Pleurotus } \\
\text { ostreatus }\end{array}$ \\
\hline 0 & 6.50 & 6.50 & 6.50 \\
3 & 5.30 & 5.30 & 5.40 \\
6 & 5.40 & 4.90 & 3.70 \\
9 & 4.60 & 3.70 & 3.50 \\
12 & 4.00 & 3.50 & 3.30 \\
15 & 3.30 & 3.50 & 3.20 \\
18 & 3.50 & 3.10 & 3.30 \\
21 & 2.90 & 3.10 & 3.20
\end{tabular}

Sumber : hasil analisis $\mathrm{pH}$ batch 3,2016

\section{KESIMPULAN}

Dari hasil penelitian ini dapat disimpulkan bahwa berdasarkan hasil analisa konsentrasi Laccase dalam broth fermentasi jamur uji bioleching diperoleh informasi fermentasi cair jamur edible mushroom Pleurotus ostreatus, Agaricus bisporus, dan Rhyzopus oligosporus dapat menghasilkan laccase. Hasil uji fermentasi dan aktivitas laccase pada substrat ABTS menunjukan aktivitas terbaiknya masing-masing adalah Pleurotus $774 \mathrm{U} / \mathrm{L}$ hari ke-21, Agaricus $484 \mathrm{U} / \mathrm{L}$ hari ke-9, dan Rhyzopus $480 \mathrm{U} / \mathrm{L}$ hari ke21. Hasil ekstraksi crude enzim sebaiknya ditindaklanjuti dengan purifikasi dan karakterisasi enzim laccase serta uji dye decolorisasi dan uji organoleptic. Hasil uji fermentasi dan ekstraksi skala lab sebaiknya ditindaklanjuti dengan fermentasi dan ekstraksi laccase skala fermentor untuk mendapat-kan prototype enzim laccase. Hasil prototype enzim laccase sebaiknya digunakan pada uji pemutihan sagu untuk mendapatkan sagu yang memenuhi standar kualitas Codex Stan 301R-2011 (regional standar for edible sago flour Asia) Osma dkk ${ }^{(29)}$

\section{PERSANTUNAN}

Ucapan terima kasih disampaikan kepada Kemenristekdikti yang telah memberikan dana riset dalam program In-Sinas dan Direktur Pusat teknologi Agroindustri, BPPT yang telah memberikan support, saran, dan bimbingan teknis selama riset berlangsung.

\section{DAFTAR PUSTAKA.}

1. Bintoro, D. ,(2012), Potensi sagu di Papua dan Papua Barat. Hasil Kajian UP4B dan IPB. Bogor
2. Bintoro, D, (2008), Bercocok Tanam Sagu. IPB. Pres. Bogor

3. Ahmad, M., (2014), Farmer empowerment to increase productivity of sago (Metroxylon sago spp) farming, International Journal on Advan-ced Science, Engineering and Information Technology, vol. 4, no.3, pp.129 133.

4. Naim, H.M., A.N. Yaakub, dan D.A.A. Hamdan., (2016), Commercialization of Sago through Estate Plantation Scheme in Sarawak: The Way Forward. Hindawi Publishing Corporation International Journal of Agronomy Volume 2016, Article ID 8319542, 6 pages

5. Hariyanto, B., (2014), Perkembangan Teknologi Produk Pangan Berbasis Sagu Guna Mendukung Ketersediaan Pangan. Orasi Pengukuhan Profesor Riset Bidang Teknologi Pangan. BPPT-LIPI. Jakarta

6. Hariyanto, B. dan P. Pangloli., (1992), Potensi dan Pemanfaatan Sagu. Kanisius. Yogyakarta http://dx.doi.org/10.1155/2016/8319542 http://www.ijehse.com/content/9/1/27

7. Brijwani, K., A. Rigdon, dan P.V. Vadlani., (2010). Review Article. Fungal Laccases: Production, Function, and Applications in Food Processing. SAGE-Hindawi Access to Research Enzyme Research Volume 2010, Article ID 149748, 10 pages doi:10.4061/ 2010/149748

8. Forootanfar, H., A. Moezzi, A., M. Aghaiekhozani, Y. Mahmoudjanlou, A. Ameri, F. Niknejad, dan M.A. Faramarzi, (2012), Synthetic dye decolorization by three sources of fungal laccase. Iranian Journal of Environmental Health Sciences \& Engineering 2012, 9-27

9. Margot, J., C. Bennati-Granier, J. Maillard, P. Blanquez, D.A. Barry, dan C. Holliger., (2013). Bacterial versus fungal laccase: potential for micropollutant degradation. $A M B$ Express 2013, 3:63. http://www.amb-express.com/ content/3/1/63

10. Kumar, V.V., S.D. Kirupha, P. Periyaraman, dan S. Sivanesan, (2011), Screening and induction of laccase activity in fungal species and its application in dye decolorization. African Journal of Microbiology Research Vol. 5(11), pp. 1261-1267, 4 June, 2011

11. More, S.S., P.S. Renuka, K. Pruthvi, M. Swetha, S. Malini, dan S.M. Veena., (2011), Isolation, Purification, and Characterization of fungal Laccase from Pleurotus sp. Enzyme Research Volume 2011, Article ID 248735, 7 
pages doi:10.4061/2011/248735. SAGEHindawi Access to Research

12. Cavallazzi, J.R.P., C.M. Kasuya, dan M.A. Soares., (2005), Screening of inducers for laccase production by Lentinula edodes in liquid medium. Brazilian Journal of Microbiology 36:383-387 ISSN 1517-8382

13. Minussi, R.C., M.A. Miranda, J.A. Silva, C.V. Ferreira, H. Aoyama, S. Marangoni, D. Rotilio, G.M. Pastore, dan N. Durán., (2007), Research P Purification, characterization and application of laccase from Trametes versicolor for colour and phenolic removal of olive mill wastewater in the presence of 1hydroxybenzotriazole African Journal of Biotechnology Vol. 6 (10), pp. 1248-1254, 16 May 2007 http://www.academicjournals.org/ AJB ISSN 1684-5315 (C) 2007

14. Sheikhi, F., M.R. Ardakani, N. Enayatizamir, S. Rodriguez-Couto, (2012), The Determination of Assay for Laccase of Bacillus subtilis WPI with Two Classes of Chemical Compounds as Substrates. Indian J Microbiol (Oct-Dec 2012) 52(4):701-707 DOI 10.1007/ s12088-012-0298-3

15. Peter, J.K., P. Vandana, H. Masih, dan Y. Kumar., (2014). Production Optimization and Partial Purification of Laccases from Bacterial Consortium. International Journal of Engineering Research \& Technology (IJERT) Vol. 3 Issue 6, June - 2014 ISSN: 2278-0181.

16. Pannu, J.S. dan R.K. Kapoor, (2014), Microbial Laccases: A Mini-Review on Their Production, Purification and Applications. Review Article International Journal of Pharmaceutical Archive-3 (12), 2014, 528536.

17. Desai, S.S., G.B. Tennali, N. Channur, A.C. Anup, G. Deshpande, dan B.P.A. Murtuza, (2011), Isolation of laccase producing fungi and partial characterization of laccase. Research Article, Biotechnol. Bioinf. Bioeng. 2011. 1(4):543-549

18. Das, N., D. Dey, dan S. Mishra, (2015). Isolation and physico-chemical characterization of extracellular ligno-cellulolytic enzymes of Pleurotus pulmonarius in submerged fermentation. International Journal of Applied Biology and Pharmaceutical Technology Volume-6, Issue3, July-Sept-2015. Coden IJABFP-CAS-USA. Copyrights @2015, ISSN: 0976-4550. www.ijabpt.com

19. Okamoto, K., O.Y. Sonoe, dan S. Takuo, (2000), Purification and characterization of extracellular laccase from Pleurotus ostreatus. Mycoscience 41: 7 - 13, 2000.

20. Trejo-Hernandez, M.R., A. Lopez-Munguia, dan R.Q. Ramirez, (2001), Residual compost of Agaricus bisporus as a source of crude laccase for enzymic oxidation of phenolic compounds. Process Biochemistry 36 (2001) 635-639

21. Kumar, R. J. Kaur, S. Jain, dan A. Kumar, (2016), Optimation of laccase production from Aspergillus flavus by design of experiment technique: Partial purification and characterization. Journal of Genetic Engineering and Biotechnology vol. 14, p. 125 $-131$

22. Sandhu, D.K. dan D.S. Arora, (1985). Laccase production and wood degradation by a white rot fungus Daedalea flavida. Enzyme Microbial. Technol., 7, p. 405-408.

23. Kalra, K., R. Chauhan, M. Shavez, dan S. Sachdeva, (2013), Isolation Of Laccase Producing Trichoderma Spp. And Effect Of $\mathrm{PH}$ And Temperature On Its Activity. International Journal of ChemTech Research CODEN (USA) : IJCRGG ISSN : 09744290 Vol.5, No.5, pp 2229-2235, July-Sept 2013.

24. Konuma, H., R. Rolle, dan S. Boromthanarat, (2012), Color characteristics of sago starch as they relate to the growth environment of the sago palm (Metroxylon sago Robb). Journal of Agricultural Technology 2012 Vol. 8(1): 273287 Available online http://www.ijataatsea.com

25. Straatsma, G., J.P.G. Gerrits, T.M. Gerrits, H.J.M. Op Den Camp, dan L.J.L.D. Van Griensven, (1991), Growth kinetics of Agaricus bisporus mycelium on solid substrate (mushroom compost). Journal of General Microbiology 137, p. 1471-1477. Printed in Great Britain 1471

26. José Renato P. J.R.P. Cavallazzi, M. Catarina, C.M. Kasuya, dan M.A. Soares, (2005), Screening of inducers for laccase production by lentinula edodes in liquid medium. Brazilian Journal of Microbiology 36:383-387 ISSN 1517-8382

27. Demissie A.G., dan A. Kumar, (2014), Isolation of Novel Bacteria Isolate from Soil for Production of Extra-Cellular Laccase Enzyme. International Journal of Emerging Technology and Advanced Engineering. Website: www.ijetae.com (ISSN 2250-2459, ISO 9001:2008 Certified Journal, Volume 4, Issue 11, November 2014) 
28. Romaní, A.M., H. Fischer, C. Mille-Lindblom, dan L.J. Tranvik, (2006), Interactions of bacteria and fungi on decomposing litter: differential extracellular enzyme activities. Ecology. 2006 Oct;87(10): 2559-69.
29. Osma, J.F., J. Toca-Herrera, dan S. Rodr'i guez-Couto, (2010), Review Article Uses of Laccases in the Food Industry. SAGEHindawi Access to Research Enzyme Research Volume 2010, Article ID 918761, 8 pages doi:10.4061/2010/918761. 